SAKAI SAMBAYAN — Jurnal Pengabdian kepada Masyarakat

\title{
PEMANFAATAN AIR DATARAN TINGGI DI DESA BATU KERAMAT KECAMATAN KOTA AGUNG TIMUR, TANGGAMUS LAMPUNG
}

\author{
Ordas Dewanto*, Bambang Irawan, Bagus S Mulyatno \\ Teknik Geofisika, Fakultas Teknik Universitas Lampung \\ Jl. Soemantri Brojonegoro no.1 35142 Bandar Lampung \\ Penulis Korespodensi : ordas.dewanto@eng.unila.ac.id
}

\begin{abstract}
Abstrak
Desa Batu Keramat Kecamatan Kota Agung Timur, Kabupaten Tanggamus Propinsi Lampung, terletak pada daerah dataran tinggi. Masyarakatnya memiliki mata pencaharian $60 \%$ bertani dan berternak. Jenis usaha yang mereka lakukan ini sangat prospek untuk ditingkatkan, karena potensi air dari dataran tinggi sangat bagus. Hasil pengolahan data resistiviti menunjukkan bahwa titik pengukuran terdiri dari 5 lapisan tanah dan batuan. Dari identifikasi kelima lapisan dapat dikatakan bahwa pada titik pengukuran tersebut tidak ditemukan keberadaan akuifer air tanah. Dengan demikian dapat disimpulkan bahwa kedalaman air tanah di Desa Batu Keramat sebelah barat berada pada kedalaman yang sangat dalam, yang di atasnya terdapat batuan yang keras sehingga tidak mungkin untuk dibuat sumur gali. Solusinya membuat sumur bor dengan biaya yang sangat mahal dan sangat sulit untuk dilakukan. Jalan satu-satunya untuk mendapatkan air yaitu dari dataran tinggi air pegunungan. Oleh karena itu tim Pengabdian Unila mengajak masyarakat Batu Keramat khususnya Mitra (H. Eko Yulianto) untuk memanfaatkan air dari dataran tinggi menuju tempat ternak, tanaman dan rumah tangga. Metode kegiatan yang digunakan dalam kegiatan ini adalah metode participatory rural approisal yang melibatkan masyarakat dalam kegiatan secara keseluruhan. Pelaksanaan kegiatan ini melalui penyuluhan, pelatihan dan demonstrasi serta evaluasi untuk melihat efektivitas program sehingga program akan tersosialisasi dengan baik serta efisien. Metode lainnya meliputi desain pembuatan alat saluran air dan tempat usaha, demonstrasi dan pelatihan. Hasil yang diperoleh saat ini yang telah dikerjakan oleh Mitra dan Tim Pengabdian Unila adalah saluran air dari bak penampung menuju bak air mitra, kolam ikan dan tanaman. Peningkatan usaha sedikit demi sedikit mengalami kenaikan, yaitu dari tanaman dan ternak.
\end{abstract}

Kata kunci: data resistiviti, akuifer air tanah, dataran tinggi, saluran air

\section{Pendahuluan}

Daerah dataran tinggi Gisting dan Batu Keramat mengandung potensi yang indah di mana dari ketinggian tempat ini kita bisa menikmati udara dingin gunung. Desa Batu Keramat memiliki topografi yang bergelombang atau berbukit-bukit. Topografi wilayahnya bervariasi antara dataran rendah dan dataran tinggi yang sebagian merupakan daerah berbukit sampai bergunung. Topografi tersebut mempengaruhi aktivitas masyarakat dan pola kehidupan masyarakatnya. Keadaan udara pada malam dan siang hari suhunya dingin baik pada musim hujan ataupun musim panas (Juniar dkk). Gambar 1 menunjukkan peta kota Bandar Lampung dan Kota Agung.

Desa Batu Keramat memiliki penduduk 1525 jiwa, 791 jiwa laki-laki dan 734 jiwa perempuan, serta terdiri dari 367 Penduduk Batu Keramat berdasarkan umur, yaitu usia (0-14 tahun) berjumlah 394 jiwa, digolongkan ke dalam penduduk belum produktif, usia dewasa (15-64 tahun) berjumlah 1.074 dari jumlah penduduk, digolongkan ke dalam produktif, sedangkan usia tua ( $\geq 65$ tahun) berjumlah 57 jiwa dan tergolong dalam kelompok usia tidak produktif.

Manfaat dataran tinggi di Desa Batu Keramat bagi kehidupan tentunya sangat banyak. Dataran tinggi atau yang biasa disebut juga sebagai Plato atau Plateau merupakan suatu area atau wilayah yang berada di daerah tinggi. Ketinggiannya mencapai hingga lebih dari 300 meter di atas permukaan laut. Ciri-ciri dataran tinggi ini yaitu cadangan air yang berasal dari mata air alami begitu cukup melimpah, kegiatan penduduk di Desa Batu Keramat sering melakukan budidaya berbagai tanaman holtikultura yang berupa sayur-sayuran, buah-buahan serta tanaman hias. Air yang berasal dari mata air dataran tinggi ditampung hanya oleh satu penampung dan belum 
maksimal dimanfaatkan oleh masyarakat Batu

Keramat.

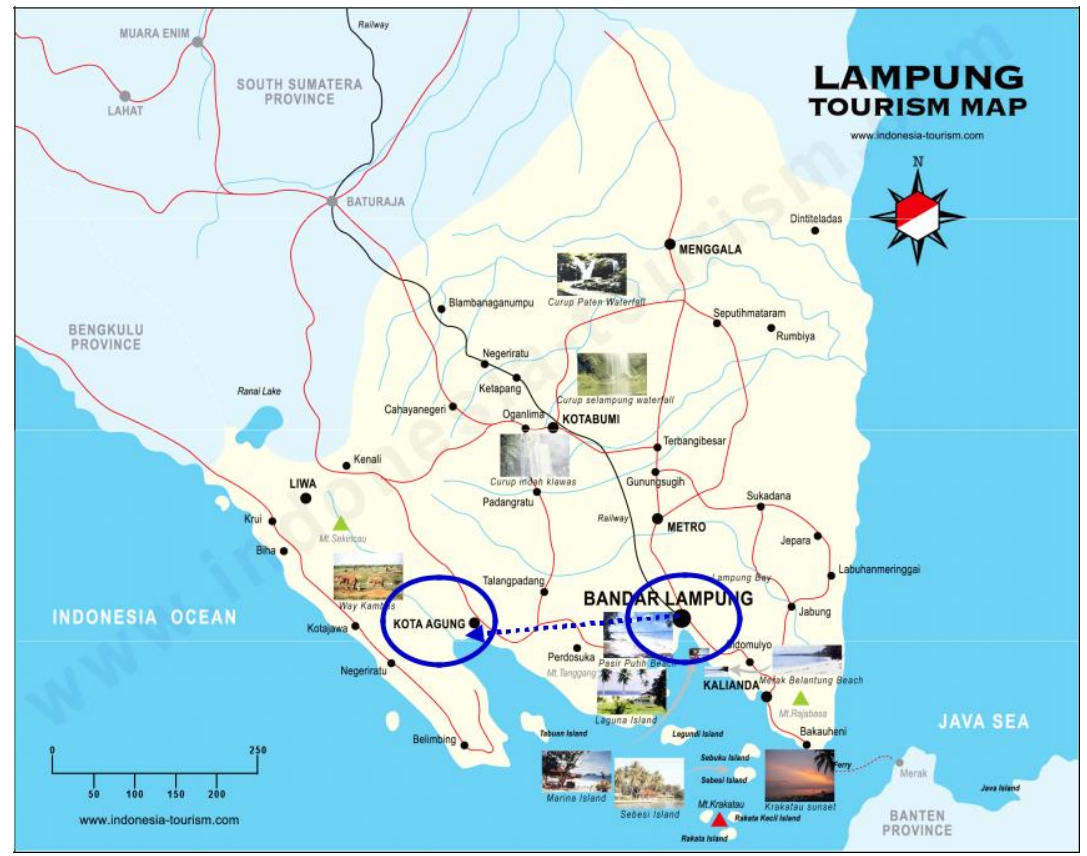

Gambar 1. Peta Bandar Lampung dan Kota Agung

Dari hasil diskusi dengan mitra/ pengusaha kecil kelompok tani dan ternak Desa Batu Keramat, Kecamatan Kota Agung Timur, Kabupaten Tanggamus disepakati bersama bahwa yang menjadi permasalahan utama di lingkungan mereka adalah:

1. Belum adanya saluran air dari dataran tinggi menuju tempat usaha mitra

2. Belum adanya tempat penampungan air pada usaha mitra

3. Belum adanya pembagian saluran air menuju tempat penampungan air, tempat ternak, tempat tanaman dan untuk rumah tangga.

4. Tempat ternak kambing dan ikan belum terbuat rapi dan belum terbuat saluran air untuk kebutuhan ternak.

5. Tempat tanaman sayuran belum ada saluran air untuk kebutuhan tanaman.

6. Mitra perlu mempunyai bak penampung air dari dataran tinggi sebagai tambahan usaha.

Tanpa air, berbagai proses kehidupan tidak dapat berlangsung, sehingga penyediaan air baku untuk kebutuhan domestik, irigasi dan industri menjadi menjadi perhatian dan prioritas utama (Samekto dan Winata, 2010). Pemanfaatan air dataran tinggi dan penentuan kedalaman air tanah, belum dilakukan oleh mitra petani dan peternak di Desa Batu Keramat Kecamatan Kota Agung Timur Kabupaten Tanggamus. Padahal hasil tani dan ternak sangat prospek di daerah tersebut. Kelemahan masyarakat Desa Batu Keramat, belum memanfaatkan air dataran tinggi dan penentuan kedalaman air tanah adalah:

1. Kurangnya inisiatif dan kreatif tentang potensi air dataran tinggi.

2. Kurangnya pengetahuan tentang pembagian saluran air.

3. Belum tahu cara membuat ternak ikan dan kambing, tanaman sayuran, tempat penampungan air dalam hubungannya dengan potensi air dataran tinggi.

\section{Metode Pengabdian pada Masyarakat}

Pada Program Kemitraan Masyarakat (PKM) ini sebelum pelaksanaan dilakukan disusun kerangka pemecahan masalah dan evaluasinya. Dari gambaran analisis situasi dan permasalahan yang dihadapi oleh mitra dan survei tim pengabdian pada khalayak sasaran, adalah bagaimana penanganan pembuatan model desain pemanfaatan air dari dataran tinggi menuju tempat usaha petani dan peternak, serta model desain saluran air pada tempat mitra. Kemudian 
bagaimana menentukan kedalaman air tanah untuk pembuatan sumur.

Metode kegiatan yang digunakan dalam kegiatan PKM ini adalah metode Participatory Rural Approisal (PRA) yang melibatkan masyarakat dalam kegiatan secara keseluruhan. Pelaksanaan kegiatan ini melalui penyuluhan, pelatihan dan demonstrasi serta evaluasi untuk melihat efektivitas program sehingga program akan tersosialisasi dengan baik serta efisien. Metode lainnya menggunakan istilah metode kaji tindak yang dalam hal ini meliputi desain pembuatan alat saluran air dan tempat usaha, demonstrasi dan pelatihan. Sasaran demonstrasi, penyuluhan dan pelatihan ditujukan pada kelompok-kelompok industri kecil petani dan peternak ikan dan kambing di Desa Batu Keramat, Kecamatan Kota Agung Timur, Tanggamus, Lampung yang menjadi sasaran.

\section{Kegiatan dan Hasil}

Survei awal di daerah pengabdian Desa Batu Keramat Kecamatan Kota Agung Timur, Kabupaten Tanggamus Propinsi Lampung, dilaksanakan pada awal tahun 2019. Pekerjaan survei awal pertama yang dilakukan adalah: Tim pengabdian bersama Mitra dan sebagian penduduk berdiskusi tentang sistem pemanfaatan air dataran tinggi, pembuatan kolam, kandang dan melakukan penentuan kedalaman air tanah untuk pembuatan sumur gali.

Dari hasil survei awal ini, mitra dan sebagian penduduk telah mengetahui tujuan dan manfaat dari kegiatan pengabdian ini. Sementara Tim Pengabdian telah mengetahui kondisi daerah pengabdian di Desa Batu Keramat Kecamatan Kota Agung Timur, Kabupaten Tanggamus Propinsi Lampung.

Schouten (2006) memaparkan beberapa data yang menyajikan fakta bahwa air sangat penting pernanannya dalam pembangunan ekonomi. Tim pengabdian kembali ke lokasi pengabdian masyarakat di Desa Batu Keramat Kecamatan Kota Agung Timur, Kabupaten Tanggamus Propinsi Lampung. Tim pengabdian beserta tim ahli serta mitra melakukan pekerjaan penentuan kedalaman air tanah, dengan tujuan untuk pembuatan sumur sebagai persiapan musim kemarau yang panjang. Gambar 2 menunjukkan Tim pengabdian bersama mitra dan warga menentukan pengukuran kedalaman air tanah di Desa Batu Keramat.

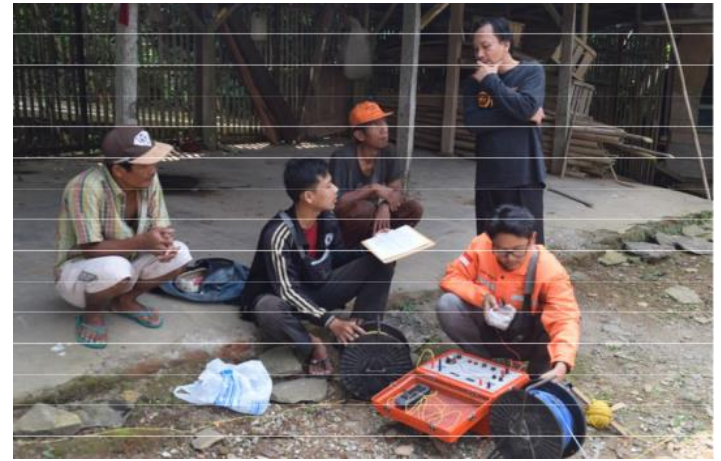

Gambar 2. Tim pengabdian bersama mitra, warga menentukan pengukuran kedalaman air tanah

Penentuan kedalaman air tanah menggunakan alat Geolistrik (Azhar, 2004). Alat Geolistrik Geolistrik adalah salah satu metode dalam geofisika yang mempelajari sifat aliran listrik di dalam bumi dan bagaimana cara mendeteksinya di permukaan bumi. Pada umumnya, metode geolistrik hanya baik digunakan untuk eksplorasi yang dangkal, sekitar $200 \mathrm{~m}$. Jika kedalaman lapisan lebih dari harga tersebut, informasi yang diperoleh kurang akurat, hal ini disebabkan melemahnya arus listrik untuk jarak bentangan yang semakin besar (Telford dkk, 1990). Nilai-nilai tahanan jenis batuan, tanah dan mineral telah ditentukan oleh Loke (2004).

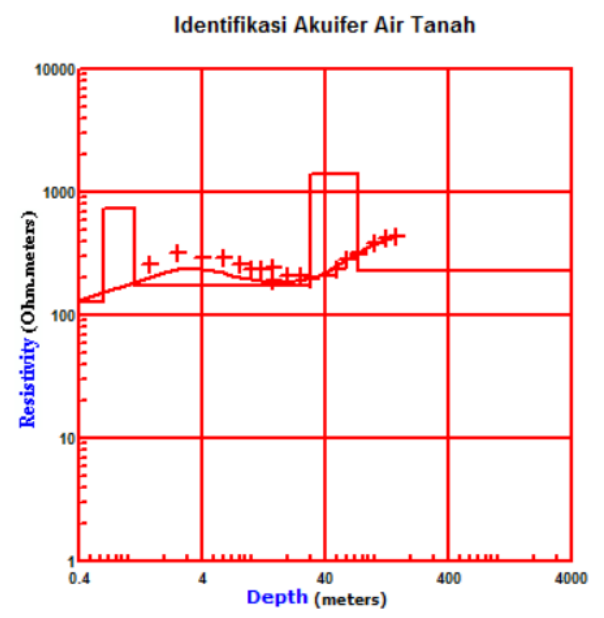




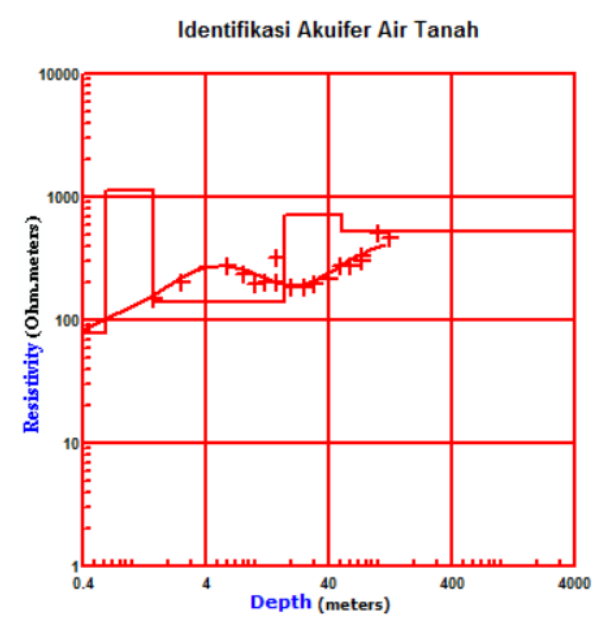

Gambar 3. Hasil pengolahan data Resistivity titik KA-01 dan KA-02 dalam grafik 1D

Berdasarkan pembacaan grafik 1D titik KA01 dan KA-02, dikatakan bahwa pada titik pengukuran terdiri dari 5 lapisan tanah dan batuan. Dari identifikasi kelima lapisan di atas, dapat dikatakan bahwa pada titik pengukuran tersebut tidak ditemukan keberadaan akuifer air tanah. Dengan demikian dapat disimpulkan bahwa kedalaman air tanah di Desa Batu Keramat sebelah barat berada pada kedalaman yang sangat dalam, yang di atasnya terdapat batuan yang keras sehingga tidak mungkin untuk dibuat sumur gali. Gambar 3 menunjukkan hasil pengolahan data Resistivity titik KA-01 dan KA-02 dalam grafik $1 \mathrm{D}$.

Solusinya membuat sumur bor dengan biaya yang sangat mahal dan sangat sulit untuk dilakukan. Peningkatan pengetahuan dan kesadaran penduduk tentang arti penting sumur sebagai upaya konservasi air tanah dan mencegah banjir, serta pengetahuan dan keterampilan membuat sumur yang berdaya guna tinggi, murah dan mudah dikerjakan oleh masyarakat merupakan tujuan yang bagus (Purwantoro dkk, 2007).

Jalan satu-satunya untuk mendapatkan air yaitu dari dataran tinggi air pegunungan. Oleh karena itu tim Pengabdian Unila mengajak masyarakat Batu Keramat khususnya Mitra ( $\mathrm{H}$. Eko Yulianto) untuk memanfaatkan air dari dataran tinggi menuju tempat ternak, tanaman dan rumah tangga. Gambar 4 menunjukkan pemanfaatan air dataran tinggi menuju mitra Desa Batu Keramat yang diteruskan ke rumah, ternak dan tanaman.

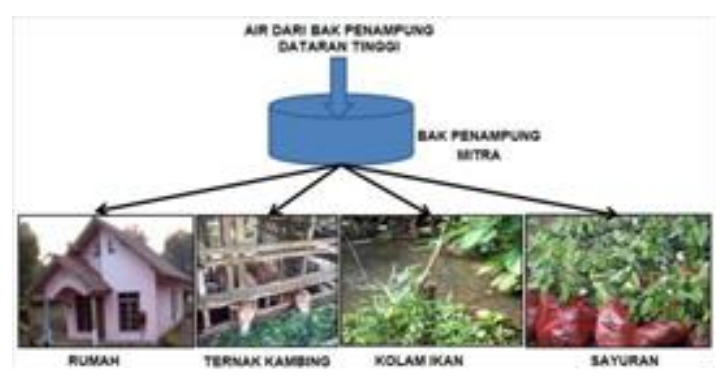

Gambar 4. Pemanfaatan air dataran tinggi menuju mitra Desa Batu Keramat

Sumber air yang digunakan oleh para petani kentang sebagian besar berasal dari mata air dan sungai (Hadi dkk, 2013). Desain pemanfaatan air dari dataran tinggi menuju tempat mitra, termasuk desain saluran air di tempat ternak, tanaman, penampungan air dan rumah tangga, telah $90 \%$ terealisasi dan dipergunakan.

Pembuatan kolam ikan, kandang kambing dan desain saluran air oleh mitra diharapkan diikuti oleh masyarakat Batu Keramat satu per satu, sehingga akan meningkatkan kelompok peternakan dan pertanian di Desa Batu Keramat, Kecamatan Kota Agung Timur, Kabupaten Tanggamus, Lampung. Usaha kelompok petani dan peternak akan bertambah maju, dilihat dari indikator hasil pemanfaatan air untuk peternakan dan pertanian. Hasil yang diperoleh saat ini yang telah dikerjakan oleh Mitra dan Tim Pengabdian Unila adalah saluran air dari bak penampung menuju bak air mitra, kolam ikan dan tanaman. Peningkatan usaha sedikit demi sedikit mengalami kenaikan, misal dari tanaman dan ternak. Gambar 5 menunjukkan hasil Tim Pengabdian Unila yang dapat meningkatkan usaha Mitra Desa Batu Keramat. 


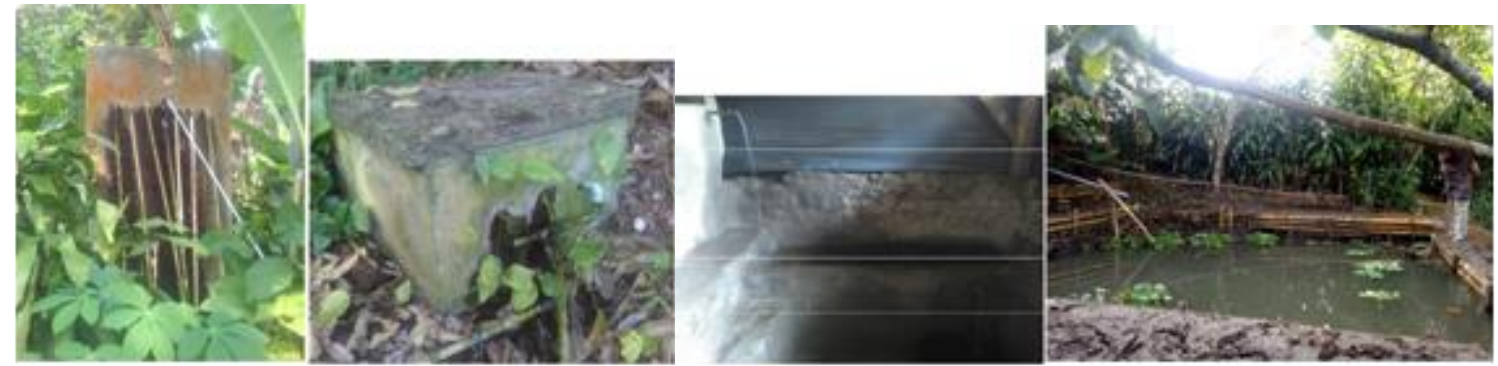

Gambar 5. Hasil pemanfaatan air dataran tinggi menuju mitra Desa Batu Keramat

Jika masyarakat Batu Keramat dapat memanfaatkan air dari mata air dataran tinggi untuk usaha mereka, maka usahanya akan semaikn bertambah maju. Peternak dan petani tersebut harus membuat tempat penampungan air dan saluran air dari mata air menuju penampungan air, tempat ternak, tempat tanaman sayuran dan rumah tangga. Kami Tim Pengabdian Program Kemitraan
Masyarakat (PKM) dari Unila membantu meningkatkan usaha masyarakat Desa Batu Keramat Kecamatan Kota Agung Timur, Kabupatan Tanggamus, dengan metode pemanfaatan air dataran tinggi menuju saluransaluran air tempat usaha masyarakat Batu Keramat. Gambar 6 menunjukkan hasil tanaman dan ternak dari pemanfaatan air dataran tinggi menuju mitra.

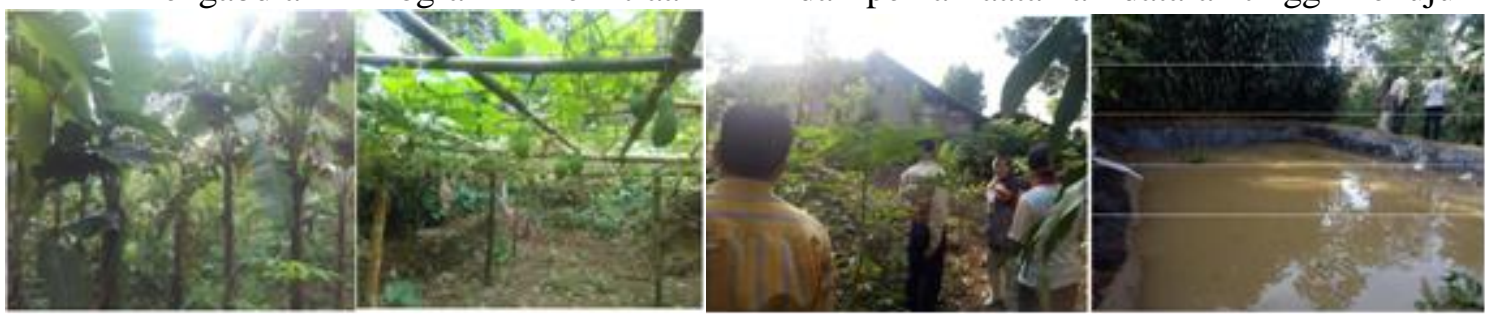

Gambar 6. Hasil tanaman dan ternak dari pemanfaatan air dataran tinggi menuju mitra

Setelah mengetahui manfaat dataran tinggi bagi kehidupan yang telah dijelaskan di atas, maka masyarakat Batu Keramat sebaiknya mulai memanfaatkan air yang ada di dataran tinggi sebaik mungkin, entah untuk perkebunan, hortikultura, perternakan atau bahkan dibuat sebagai hutan. Usaha pelestarian tanah dari bahaya erosi juga perlu dilakukan supaya tanah tidak cepat tandus karena terlalu banyak lapisan tanah bagian atas yang larut oleh air hujan. Lahan pada dataran tinggi juga bisa digunakan sebagai areal pertanian dengan menggunakan cara hortikultura.

Hortikultura merupakan kegiatan memperbanyak jenis tanaman yang dipelihara pada sebuah lahan pertanian. Tujuan penanaman secara hortikultura adalah meningkatkan hasil pertanian serta mengurangi resiko gagal panen. Selain itu, hortikultura juga bertujuan supaya tanah yang ada pada dataran tinggi tetap hijau dan tidak terkena erosi.

Lahan perkebunan pada dataran tinggi Desa Batu Keramat sangat subur, dimanfaatkan untuk menanam kopi, teh, kina serta sayurVol 4 No 1 Maret 2020 sayuran. Oleh karena itu, lahan yang ada di dataran tinggi atau daerah pegunungan perlu dilestarikan. Lahan di dataran tinggi juga sangat cocok dijadikan tempat usaha perternakan. Jenis ternak yang dipelihara tentunya harus disesuaikan dengan keadaan iklim setempat, mengingat tanah yang ada di dataran tinggi memiliki iklim yang sejuk. Lahan dataran tinggi juga sangat baik dijadikan sebagai hutan, karena hutan pada dataran tinggi begitu sangat penting guna mencegah terjadinya erosi tanah, melindungi dan menjaga kesuburan tanah, serta menyimpan cadangan air.

\section{Kesimpulan}

Desain pemanfaatan air dari dataran tinggi menuju tempat mitra, termasuk desain saluran air di tempat ternak, tanaman, penampungan air dan rumah tangga, telah $90 \%$ terealisasi dan dipergunakan.

Usaha kelompok petani dan peternak bertambah maju, dilihat dari indikator hasil pemanfaatan air untuk peternakan dan pertanian. 
Hasil pengukuran dengan metode Geolistrik dalam penentuan kedalaman air, untuk sementara diketahui kedalaman air tanah ada yang dalam dan dangkal

Pembuatan kolam ikan, kandang kambing dan desain saluran air oleh mitra diharapkan diikuti oleh masyarakat satu per satu, sehingga akan meningkatkan kelompok peternakan dan pertanian di Desa Batu Keramat, Kecamatan Kota Agung Timur, Kabupaten Tanggamus, Lampung.

\section{Ucapan Terimak Kasih}

Terima kasih kami sampaikan kepada Dikti yang telah mendanai pengabdian ini, sehingga pengabdian ini dapat berjalan lancar dan tanpa kendala.

Terima kasih juga kami sampaikan kepada LPPM Unila yang telah memberikan kesempatan melakukan pengabdian dan bimbingan dalam pelaksanaan pengabdian.

Terimakaasih juga kami sampaikan kepada Mitra (H. Eko Yulianto) yang bersedia diajak kerja sama sehingga kegiatan pangabdian ini berjalan dengan lancar.

\section{Daftar Pustaka}

Azhar dan Handayani G. 2004. Penerapan Metode Geolistrik Konfigurasi Schlumberger untuk Penentuan Tahanan Jenis Batubara. Jurnal Natural Indonesia. Vol 2 hal 22.

Budiman, A., Delhasni dan Widjojo, S.A.A.H. 2013. Pendugaan Potensi Air Tanah Dengan Metode Geolistrik
Tahanan Jenis Konfigurasi Schlumberger. Jurnal Ilmu Fisika (JIF), Vol. 5 No.2. ISSN: 1979-4657.

Hadi S., Mulyono, A. dan Marganingrum,

D. 2013. Potensi Sumberdaya Air Kawasan Dataran Tinggi Dieng Bagi Pemanfaatan Air Irigasi. Prosiding Pemaparan Hasil Penelitian Puslit Geoteknologi. LIPI. Hal: 365-371. ISBN: 978-979-8636-20-2.

Hendrajaya, L. dan Arif, I. 1988. Geolistrik Tahanan Jenis. Laboratorium Fisika Bumi. Jurusan FMIPA. ITB. Bandung.

Loke, M.H. 2004. RES2DINV ver.3.3 for Windows 3.1, 95 and NT: Rapid $3 D$ Resistivity \& IP Inversion Using The Least-Squares Method. Penang. Malaysia.

Purwantoro, S., Hadi, B.S. dan Khotimah, 2007. Pelatihan Dan Sosialisasi Pembuatan Sumur Resapan Untuk Masyarakat Perdesaan Di Kecamatan Ngaglik Bagian Utara Kabupaten Sleman Laporan Kegiatan Pengabdian Pada Masyarakat (PPM) Dosen. Jurusan Pendidikan Geografi Fakultas Ilmu Sosial Dan Ekonomi, Universitas Negeri Yogyakarta.

Riska Juniar, R., Sugiyanta, I.G., Haryono, E.

Samekto, C dan Winata, E.S. 2016. Potensi Sumber Daya Air di Indonesia. Seminar Nasional. BPPT. Jakarta.

Schoon, J.H. 1996. Physical Properties of Rock Fundamentals and Principal of Petrophysic. Pergamon. Australia.

Telford, V.M, Gerald, L.P dan Sheriff, R.E.1990. Applied Geophysics $2^{\text {nd }}$ Edition. Cambridge University Press. New York. 